\title{
Roles and responsibilities of open innovation specialists based on analysis of job advertisements
}

\author{
Justyna Dąbrowska, Daria Podmetina \\ School of Business and Management, LUT Kouvola, Lappeenranta University of \\ Technology, Kouvola, Finland \\ \{justyna.dabrowska, daria.podmetina\}@lut.fi
}

\begin{abstract}
Innovative companies are increasingly creating new open innovation functions and employing open innovation specialists to facilitate innovation processes. However, research that explores these emerging jobs remains scarce. This study examines the worldwide job market for 'open innovation' specialists as per job title and/or job description, and analyzes 100 job advertisements related to 'open innovation' specialists published during two periods in 2014 and 2016. The findings identify the key responsibilities of dedicated open innovation specialists and associated skills, and the competencies that companies seek in candidates. In addition, the findings indicate that companies need open innovation specialists to not only work in R\&D departments. In addition, the ability to influence others and prior start-up experience have become basic requirements to apply for open innovation specialist positions.
\end{abstract}

Keywords. Open innovation, job skills, competencies, job description, open innovation specialist, job advertisement, roles.

\section{Introduction}

Since 2003, when Henry Chesbrough introduced the term 'open innovation' (OI), it has become very popular among scholars and practitioners. Many firms have opened up their companies' boundaries and embraced open innovation as a business strategy (Chesbrough and Bogers, 2014; Dahlander and Gann, 2010; Gassmann et al., 2010; Mortara and Minshall, 2014). Open innovation adoption requires changes in the organizational structure and work practices of R\&D professionals (Salter et al., 2014), and the redefinition of tasks, tools, processes and reward systems (e.g. Alexy et al., 2014; Mortata et al., 2014). Considering the intensity of necessary changes related to the personnel involved in open innovation, academic research has paid little attention to the human side of open innovation (Bianchi et al., 2011; Bogers et al., 2018; Podmetina et al., 2013; Mortara et al., 2014; Salter et al., 2014; Vanhaverbeke et al., 2014; West et al., 2006; Wynarczyk et. al., 2013). 
According to the report of the Word Economic Forum on the Future of Jobs (WEF, 2016), disruptive changes to the business models, together with the other major drivers of global transitions, are expected to have a significant impact on creating new jobs that did not exist a few years ago. Indeed, this rapid change is also observed in companies as open innovation functions and new roles are formalized (Alexy et al., 2014; Dabrowska and Podmetina, 2014; Mortara and Minshall, 2014). In addition, new open innovation job titles have emerged, and a LinkedIn search reveals over 52,000 job titles related to "open innovation", only 15 years after the introduction of the term (LinkedIn, 2018).

Apart from creating new jobs, the adoption of open innovation practices also changed the way companies recruit new staff, and what skills and competencies they are seeking (Di Minin et al., 2010). Once a company decides to open up its innovation process, employees are expected to possess certain competencies and skills in addition to technical/scientific or managerial expertise (Bredin and Söderlund, 2006; Huston and Sakkab, 2006). However, the description of these required competencies and skills remains vague.

At the same time, the confusion about the nature of the open innovation term (Trott and Hartmann, 2009) and the different processes and practices associated with it, leads to asking what the roles and responsibilities are of open innovation specialists. To the best of our knowledge, before this study, there was no prior attempt to analyze the job advertisements related to open innovation that aimed to identify the skills, roles and responsibilities of open innovation specialists in companies. Thus, by analyzing the job market, this paper focuses on identifying common skills and competencies of open innovation specialists, as well as their roles and responsibilities. Moreover, it analyses the differences in competence profiles across organizations and differences of organizational functions where open innovation specialists are needed.

The main research questions are:

(Q1): What are the roles and responsibilities of open innovation specialists in a company?

(Q2): What common competencies do organizations seek from open innovation specialists?

(Q3): What are the differences between competence profiles and job responsibilities across organizations?

Given the sparse literature on the topic, we answer these questions through a qualitative analysis of job offers posted worldwide and collected during two periods: February 2014 and February 2016. One hundred job advertisements with 'open innovation' in the job title or job description were analyzed.

The remainder of this paper comprises five sections. In the next section, we present the theoretical foundations of the human side of open innovation and related skills and competencies. Next, we describe the research design and methodology. In section four we present the findings, which is followed by a discussion and conclusions. 


\section{Theoretical background}

\subsection{Open innovation}

Open innovation was originally presented as a paradigm shift for high-tech industries, e.g. large manufacturing firms (Laursen \& Salter, 2006), chemicals (Kirschbaum, 2005), pharmaceuticals (Lichtenthaler, 2008, Lichtenthaler, 2007, Lichtenthaler \& Ernst, 2008, Lichtenthaler, 2010; Thong and Lotta, 2015), electronics (Christensen et al., 2005), automotive (DiMinin et al., 2010), and communications (Asakawa et al., 2010). It can be observed that today, research has also expanded to a wide range of other industries (Chesbrough and Bogers, 2014). Open innovation can be defined as "the use of purposive inflows and outflows of knowledge to accelerate internal innovation, and expand the markets for external use of innovation, respectively." (Chesbrough, 2006b, p. 1). However, after being criticized about the lack of a proper definition of open innovation (e.g. Knudsen \& Mortensen, 2011; Ozman, 2008; Trott \& Hartmann, 2009) and after applying recent conceptualizations (Gassmann and Enkel, 2004; Dahlander and Gann, 2010; West and Bogers, 2014), a few years later the definition was re-defined as a "distributed innovation process based on purposively managed knowledge flows across organizational boundaries, using pecuniary and nonpecuniary mechanisms in line with the organization's business model" (Chesbrough and Bogers, 2014, p. 17).

As the concept gained interest from academia, several classifications of open innovation activities emerged. For example, Gassmann and Enkel (2004) classified the open innovation process as the outside-in, the inside-out, and the coupled process. Chesbrough et al. (2006) distinguished the purposive inflows and outflows of knowledge into inbound and outbound open innovation. Inbound open innovation reflects the outside-in process, and outbound open innovation the inside-out process. Later, Dahlander and Gann (2010) emphasized the monetary directions of the knowledge flows by adding the pecuniary and non-pecuniary dimensions to this classification. As a result, they distinguished two forms of inbound innovation acquiring and sourcing, and two forms of outbound open innovation - selling and revealing. Following the classifications by Gassmann and Enkel (2004) and Dahlander and Gann (2010), in their latest work Chesbrough and Bogers (2014) defined the mechanisms to help in managing the knowledge flows in open innovation. For the purpose of this study, we will apply the classification of open innovation (inbound, outbound and coupled) and supporting mechanisms described by Chesbrough and Bogers (2014). 


\subsection{Skills, competencies, roles and responsibilities of open innovation specialists}

Many practitioners and researchers in academia use the term 'skills' and 'competencies' interchangeably (as an example, see section on the analysis of job advertisements). However, skills should be treated as one of the integral elements of competencies, along with "motivation, character traits, knowledge and behaviour" (Proctor and Dutta, 1995, p. 19). According to Colombo and Grilli (2005), skills of an individual are associated with educational background (e.g. Bachelor, Master, Doctoral level), their nature (e.g. engineering, economic), and length of professional experience (e.g. prior employers, prior position).

There is also a vast confusion in regard to competencies, which is often reflected in the inconsistent use of terms, as well as different understandings, e.g. based on cultural differences (Boon and van der Klink, 2002; Cseh, 2003). Most researchers use the term "competency" for describing essential human knowledge, attitudes, and skills at work (Du Chatenier et al., 2010; Sandberg, 2000) and abilities to perform non-routine tasks (Kanungo and Misra, 1992). Competencies can be defined as the "abilities to successfully meet complex demands in a particular context through the mobilization of psychosocial prerequisites (including both cognitive and non-cognitive aspects)" (Rychen and Salganik, 2003, p.43) or simply, as an integrated set of "knowledge, attitudes, and skills of a person" (Mulder, 2007, p.11). As noted by Kamoche (1996) many researchers and practitioners have composed behavioral profiles of generic competencies that are used for performance evaluation or recruitment. For the purposes of this paper, we will follow the simplified definition of competencies, described by Mulder (2007) and apply it to competencies of open innovation specialists.

Since open innovation requires opening up companies' boundaries (Chesbrough, 2003) and comprises complex activities and mechanisms that companies can adopt, it also includes various tasks that range from technical to marketing and legal (Bianchi et al., 2011) followed by a variety of job responsibilities that are associated with certain personal traits. For example, Chesbrough (2003) identified two critical traits - risk propensity and pragmatism - that are needed to overcome the so-called 'Not-Sold-Here Syndrome' (Katz and Allen, 1982). While analyzing the role of licensing managers, Bianchi and colleagues (2011) emphasized the mediating attitude in terms of conflict minimization between internal and external stakeholder, and systemic approach. Du Chatenier et al. (2010) analyzed open innovation teams' competencies, and pointed out the three most important competencies that individuals working in these teams should possess: combinatory skills, social astuteness, sociability. Several consulting books also describe needed skills for open innovation teams (e.g. Hafkesbrink and Schroll, 2010; Lindegaard and Kawasaki, 2010; Sloane, 2011), however, these descriptions are mainly based on authors' own experience. The study by Sartori and colleagues (2013) compiles some of these characteristics of individuals that are needed for working in open innovation teams. They mention for example entrepreneurial mindset, communication skills, ability to comprehend complex requirements, relationship building, curiosity, holistic point of view. The report by Mortara et al., (2009) distinguishes four categories of skills for open innovation: introspective, extrospective, interactive and technical, and the accompanying set of desirable personal attributes. Concerning entrepreneurial mindset, the study by Di Minin and colleagues (2010) provides evidence that firms that adopted open innovation have changed the way they 
recruit new staff. FIAT, for example, includes entrepreneurial attitude in the assessment of new personnel. Several other papers (e.g. Cloyd and Euchner, 2012; Dodgson et al., 2006; Di Minin et al., 2010) also mention the need for stimulating entrepreneurial behavior in R\&D departments. Soft skills such as passion and optimism of managers in OI-driven organizations are emphasized by Martino and Bartolone (2011). Another study (based on an Italian sample) by Petroni and colleagues (2012) explores how the adoption of OI has changed the organizational structures of R\&D and HR practices. They conclude that, with the shift from closed toward open innovation, the greater value is placed on engineers who are capable to work in an external environment and have project management skills. The new roles have been identified in these organizations, involving technological monitoring, gatekeeping (Chen et al., 2004), boundaryspanners or so-called "T-shaped managers" (Chesbrough, 2012). Based on case study of Philips, Hacievliyagil and Auger (2010) also emphasize that researchers have changed their working time allocation, as they spend their time on business aspects (e.g. negotiation of partners, scouting for external ideas) apart from work in research labs. Fleming and Waguespack (2007) noted that leaders in open innovation communities need to possess certain social capital, defined as the boundary-spanning or brokerage of collaborative relations, apart from technical expertise. The study by Saebi and Foss (2015) argues that in order to successfully implement open innovation companies should align the organizational aspects with employed open business model. This includes designing new organizational roles and supporting governance mechanisms. For example, by adopting a market-based innovation strategy, R\&D employees should develop expertise in communicating and interacting with researchers and managers across various industries ( $T$-shaped managers); for network-based innovation strategy, the emphasis should be placed on integration experts who facilitate the integration of externally acquired knowledge across different internal units.

Mortara and Minshall (2014) noted that as the role of open innovation in companies has become strategic, new functions and roles have emerged that are explicitly linked with open innovation. For example, they mentioned the positions as Vice President for Open Innovation at Unilever, or Open Innovation Director at Crown Packaging and Philips, as examples of newly created jobs. With regard to positions of open innovation managers, the recent report by Vanhaverbeke and colleagues (2017) explores their LinkedIn profiles, but not in terms of their roles and responsibilities on the job.

Nevertheless, to the best of our knowledge, there has been no prior attempt to analyze the job offers related to open innovation to identify skills and responsibilities of open innovation professionals in companies, which this study attempts to do.

\section{Research Design and Methodology}

Employing an open innovation specialist is emerging management practice, as the concept of open innovation was only introduced in 2003. Hence, the research on their roles and responsibilities is still at a very early stage. The aim of this paper is to explore the roles, responsibilities and competencies of dedicated open innovation specialists, thus we adopted a qualitative research strategy. This strategy allows seeking answers to "what", "why", and "how" questions (Yin 2014), and thus is particularly suitable for the study. This study intends to analyse the documentary evidence by means of content 
analysis (Boettger and Palmer, 2010; Krippendorff, 2013). Qualitative content analysis in particular can be used to describe a phenomenon, allowing researchers to understand the social reality in a subjective way (Carliner et al., 2015; Zhang and Wildermuth, 2009). This inductive approach to analysis and purposively selected samples (Carliner et al., 2015; Krippendorf, 2013) yields light on general job descriptions that represent the overall view of OI positions, based on the formal description of job advertisements. Carliner and colleagues (2015) who used qualitative content analysis of job descriptions to analyze performance consultants' positions, used a similar justification and approach. However, their work does not consider job descriptions included in job advertisements.

Due to the very limited research on competencies for OI specialists and their roles from the academic perspective, we decided to analyse current job advertisements related to OI in order to investigate what common skills and competencies companies are seeking while recruiting new staff, as well as the roles and responsibilities of open innovation specialists. Although this method has not been used before in the field of OI (except one documented attempt by Ziebarth and colleagues (2010), who developed software tool to match competence profiles with job offers to support competence management for open innovation), other disciplines successfully use content analysis of job advertisements to study emerging phenomena in their field. For example, Aguinis and colleagues (2005) used it to analyze certified HR professionals, Chen and Zhang (2015) for data management professionals, Park and Lu (2009) for metadata professionals, and many others in the field of e.g. health education (e.g. Baker and Cissell, 1994) or librarian education (Shahbazi et al., 2016: Shank, 2006; Tang, 2013).

The job offer analysis, which aimed to study job advertisements listed by companies worldwide, was done in two steps - the first search was done at the beginning of 2014 and the second about two years later. In both cases, the careerjet.com search engine was used, due to the fact that it compiles job offers from different international and national sources. Even though this website is very useful when searching for job offers, it must be kept in mind that most of the job advertisements are repeated, as most companies choose many different channels to post their jobs. The keyword used was "open innovation" in the job title, job description, or job function. Out of 354 and 484 job advertisements in 2014 and 2016 respectively, 100 were selected for the analysis after the exclusion of duplicates and according to other criteria (e.g. "open innovation" used in the general companies' description, job offer posted in English). The main limitation of this study is also related to the main criterion - job advertisements in English - that excluded job offers written in local languages.

All job offers were collected in an MS Excel dataset that was later exported to Nvivo10 software, where the analysis took place. Wordle.net was used for the analysis.

Fig. 1 presents the countries where the jobs were advertised. In both analyzed years, most of them were posted in the USA (33 in 2015 and 25 in 2016). In 2016, Germany was second (4 jobs), followed by China (3), the Netherlands (3), and countries such as Canada, Thailand, Switzerland and Ireland, that had not featured in 2014. 


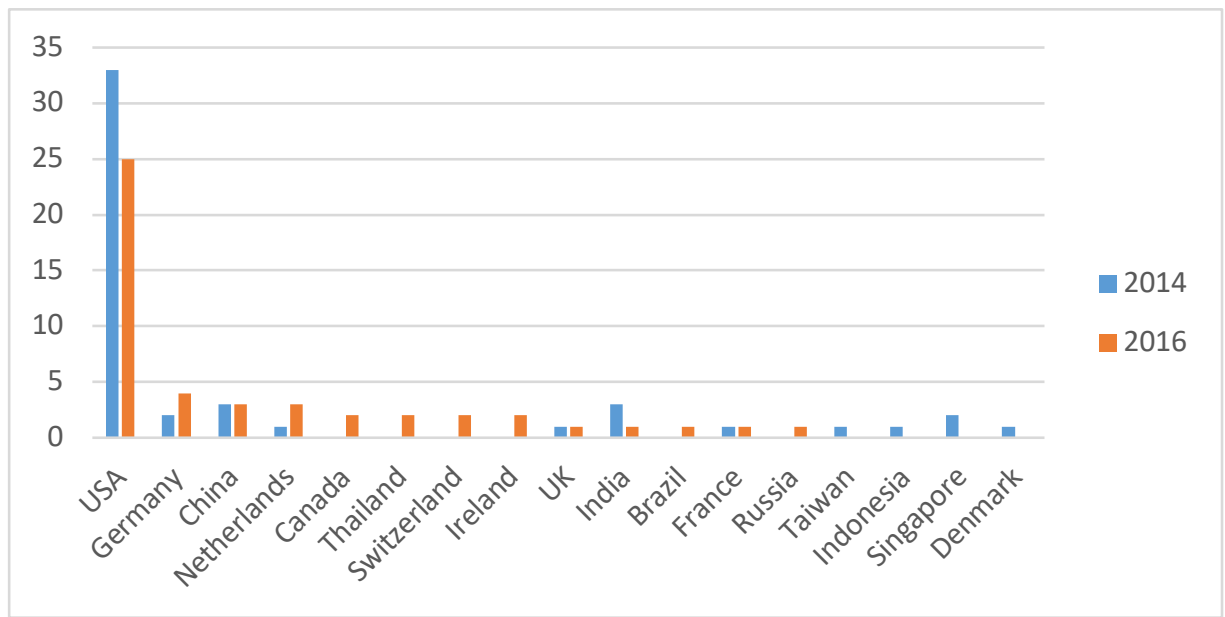

Fig. 1. List of countries with open innovation job posting in February 2014 and 2016.

It is important to note that the analyzed job offers include all available offers at different stages of a career - from internship positions to the director or head of a unit.

\section{$4 \quad$ Findings}

The analysis is presented in three blocks. The first block provides findings based on the general overview of the total sample. The second block focuses on jobs from two periods (2014 and 2016) that include 'open innovation' in the job title only. The third block compares the results from 2014 with those from 2016 based on the whole sample of 100 job offers.

\subsection{Overview of job advertisements in the field of open innovation}

As mentioned in the research design section, the selected job advertisements included 'open innovation' in the title of the job, in the description of roles and responsibilities, or in the job function. It was observed that out of 100 jobs related to open innovation, 23 mentioned 'open innovation' professional directly in the job title. In 2014 there were four (4) explicit 'open innovation' positions, compared to 19 in 2016, which indicates the growing role of open innovation in companies' structures.

There are many job offers that only mention 'open innovation' in the job description, usually in one of five ways:

1) The ideal candidate for the position needs to have a knowledge of how to best leverage open innovation platforms to source innovation.

2) The candidate will manage and grow the project pipeline via both internal and open innovation.

3) The candidate needs to have knowledge and experience in identifying innovative partnerships and executing collaborative models for partnership in the spirit of open innovation'. 
4) The candidate will internally promote the different Open Innovation activities and identify specific needs for them.

5) The candidate will be working in open innovation environment.

In total, out of 100 jobs related to open innovation, $40 \%$ were for managerial, $14 \%$ for directorial, and $10 \%$ for senior positions. Fig. 2 presents the word buzz of other position titles related to open innovation (after excluding the most common "open innovation", "manager", "director", "senior"). The results indicate that companies seek leaders, engineers, business development managers, product (marketing) managers, analysts, technology scouts, event managers, new business opportunity managers, and business strategy managers.

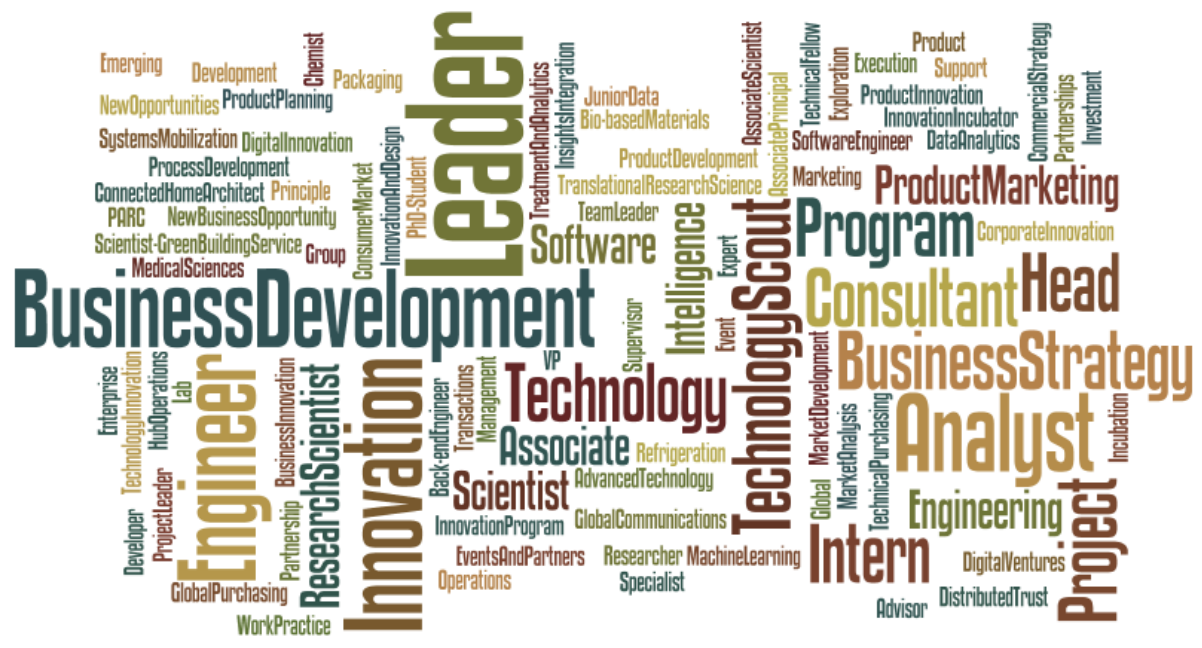

Fig. 2. Word buzz of job titles in the field of open innovation.

Another finding is that the positions related to open innovation are not only located in $\mathrm{R} \& \mathrm{D}$ departments but are also divided between other organizational functions. These include strategic management, marketing and sales, corporate communications, IT, and purchasing divisions. This adds to the notion of the multidisciplinarity of open innovation, and the tasks and responsibilities of open innovation specialists.

In regard to industries, it was noticed that even though open innovation was originally comprehended as a paradigm shift for large manufacturing firms, it has rapidly extended to new industries including service industries, supporting the insights of Chesbrough (2011) and Chesbrough and Bogers (2014). The consumer goods industry displayed the highest demand for open innovation specialists, followed by the consulting, pharmaceutical, telecommunications, electronics and healthcare sectors (see Fig. 3). 


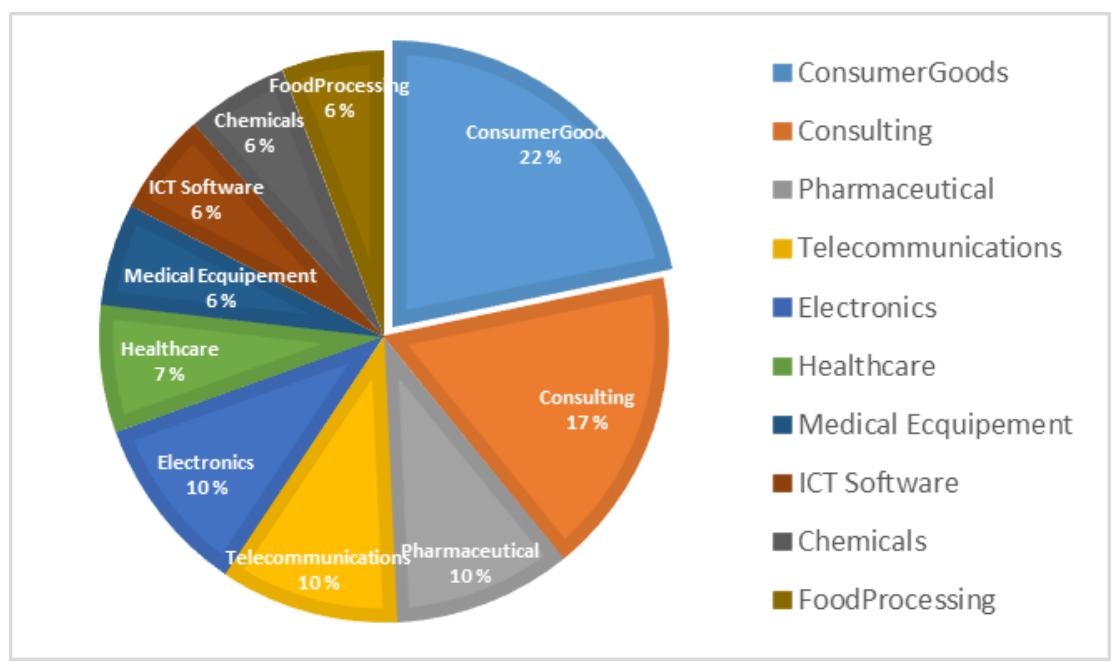

Fig. 3. The structure of the top 10 industries with job offers related to open innovation.

\subsection{The 'Open Innovation' specialist - commonalities and differences}

Interestingly, the analysis of 23 positions that directly named open innovation professionals found support for findings from another study, which argues that companies define open innovation differently and might have difficulties with identifying which practices can be perceived as open or closed (Dabrowska et al., 2013). To picture it, we used Chesbrough and Boger's (2014) classification of open innovation activities and counted the number of activities mentioned as part of the open innovation specialists' job responsibilities (See Table 1). The analyzed companies stated between four (4) and 11 different OI activities in their job descriptions. The median value was eight. All firms indicated that the candidate should have expertise in inbound open innovation (scouting for new ideas and technologies outside and collaborating with intermediaries, suppliers and customers), $43 \%$ of the firms expected the OI specialist to be responsible for the cooperation with universities, and $21 \%$ for the cooperation with start-ups. A significant number of the analyzed job profiles (over $69 \%$ ) stressed that one of the responsibilities of the job is the cooperation within ecosystems or networks or with stakeholders. For the inside-out mechanisms of OI, the most commonly mentioned responsibilities were those related to joint ventures, networks and alliances (over 21\%) and activities related to start-ups: spin outs, incubation etc. (over 21\%). 
Table 1. The number of open innovation activities indicated in 23 job advertisements related to open innovation specialists.

\begin{tabular}{|c|c|c|c|}
\hline & & $\begin{array}{l}\text { Number of companies who mention } \\
\text { the activity as part of the open } \\
\text { innovation specialist's responsibility }\end{array}$ & $\%$ \\
\hline \multirow{10}{*}{$\frac{.}{\frac{1}{2}}$} & scouting & 23 & 100,00 \\
\hline & in-licensing IP & 2 & 8,70 \\
\hline & university research programs & 10 & 43,48 \\
\hline & $\begin{array}{l}\text { funding start-up companies in } \\
\text { one's industry }\end{array}$ & 5 & 21,74 \\
\hline & $\begin{array}{l}\text { collaborating with } \\
\text { intermediaries, suppliers and } \\
\text { customers }\end{array}$ & 23 & 100,00 \\
\hline & $\begin{array}{l}\text { utilizing non-disclosure } \\
\text { agreements }\end{array}$ & 0 & 0,00 \\
\hline & crowdsourcing & 3 & 13,04 \\
\hline & competitions and tournaments & 2 & 8,70 \\
\hline & communities & 0 & 0,00 \\
\hline & spin-ins or spin-backs & 0 & 0,00 \\
\hline \multirow{6}{*}{ 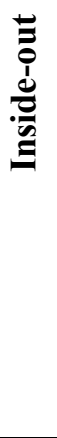 } & out-licensing IP and technology & $2+2$ & 17,39 \\
\hline & donating IP and technology & 0 & 0,00 \\
\hline & spin-outs & 5 & 21,74 \\
\hline & corporate venture capital & 0 & 0,00 \\
\hline & corporate incubators & 5 & 21,74 \\
\hline & $\begin{array}{l}\text { joint ventures and alliances (i.e., } \\
\text { becoming a supplier to or a } \\
\text { customer of a new initiative, vs. } \\
\text { executing the initiative } \\
\text { internally). }\end{array}$ & 5 & 21,74 \\
\hline \multirow[t]{4}{*}{ 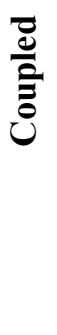 } & $\begin{array}{l}\text { strategic alliances, joint } \\
\text { ventures, consortia, networks, } \\
\text { ecosystems and platforms, all } \\
\text { involving complementary } \\
\text { partners }\end{array}$ & & \\
\hline & networks & 23 & 100,00 \\
\hline & joint ventures & 5 & 21,74 \\
\hline & ecosystems & 16 & 69,57 \\
\hline
\end{tabular}

Source: Author's own analysis, based on Chesbrough and Bogers (2014) classification of open innovation activities

In regard to job responsibilities, one position for an open innovation professional in the chemical industry in an R\&D division went beyond the tasks on R\&D or innovation management, and involved tasks from HR management (talent management, interviews 
with candidates, training). For example, apart from responsibilities like:

"Drive Open Innovation: initiate new research projects with academic and industrial partners (...) Generate and monitor new collaboration projects (...) Motivate and coach colleagues to drive (open) innovation on Innovation Campus, further develop innovation culture, support innovation processes from idea finding to project start (...) Organize open innovation workshops with customers.", it also included:

“(...) organization of events and workshops at universities, represent and present the company at universities (...) Talent Management (...) further develop concept of talent management. (...) Push development of competencies of PhD candidates and PostDocs, including feedback, and organization of trainings (...) Conduct competency-based interviews with candidates".

This may indicate that the roles and responsibilities, and related to them the skills of open innovation professionals, are becoming more interdisciplinary.

Nonetheless, common skills that the candidate should possess were also identified. Fig. 4 presents the word buzz of the common skills, which indicates that the ideal candidate should have excellent communication, leadership and project management skills; have problem-solving skills and be able to think strategically and work in cross-functional teams; possess excellent interpersonal skills; be able to work independently and as part of the team, and have the ability to influence others. Concerning knowledge, most of the job advertisements mention cross-disciplinary knowledge (be it the combination of technology and business; R\&D with marketing and management or R\&D and sales management) however, more attention in placed on prior work experience and proven track record.

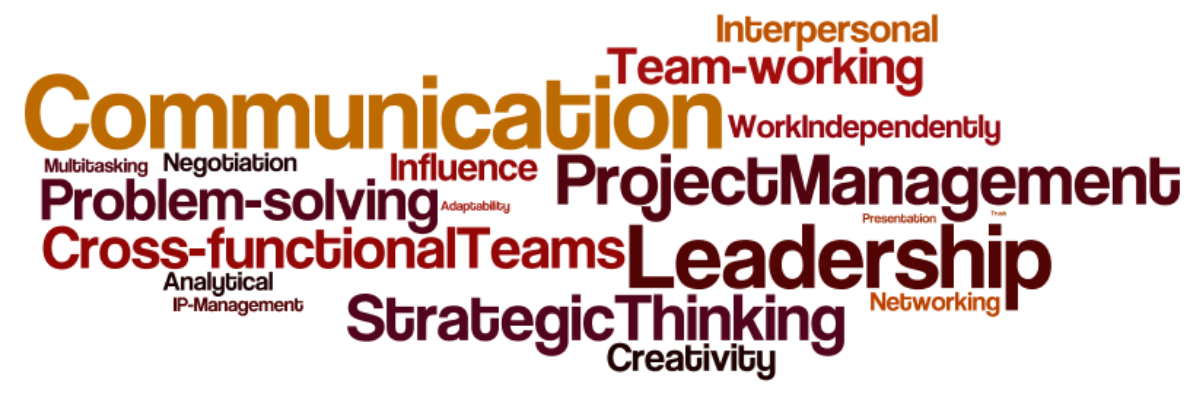

Fig. 4. Word buzz of common skills for open innovation professionals based on job advertisement analysis.

Based on the analysis of 23 positions, all naming 'open innovation' in the job titles, we can also map the key areas of roles and responsibilities of 'open innovation' professionals. Table 2 presents the summary, with examples taken directly from the job advertisements. The key areas are named in descending order, which means that scouting was mentioned the most often (as part of each and every job responsibility of an open innovation professional). Hence, one of the main responsibilities of this professional would have been scouting for technologies, ideas, solutions and/or 
business opportunities. It is followed by developing, managing, building innovation ecosystems and strategic partnerships. Also, the person was expected to create and develop open innovation strategies for the company and manage multiple projects. From the internal perspective, the person was expected to organize, plan, and manage cross-functional initiatives within the company to promote open innovation initiatives. What was less emphasized, but still relatively common, was building and designing prizes and challenges for open innovation platforms and internal and external crowdsourcing initiatives. Furthermore, the person was expected to organize and participate in open innovation events and workshops as well as to support the structuring of strategic deals.

Table 2. Key areas of roles and responsibilities based on analysis of 23 job offers with

\begin{tabular}{lc}
\hline Key areas of responsibility & Examples of Roles and Responsibilities \\
\hline Scouting for technologies, & Scout for innovative and disruptive technologies, \\
ideas, solutions, business & Scouting technologies or business opportunities at \\
opportunities & universities, institutes, or companies, incl. start-ups \\
& Build and implement state-of-the-art digital scouting \\
& capability that provides early warning to emerging \\
& disruptive technologies and opportunities \\
& Evaluate research and new technologies, identify promising \\
& candidates, and articulate possibilities to technical and \\
& non-technical stakeholders \\
& Identify strategic innovation targets (startups and/or early \\
& stage technologies \\
\hline Develop and influence the innovation ecosystem to drive \\
capability, scout for emerging technology, foster external \\
partnerships and incubate strategic collaborations \\
Engage the broader ecosystem including academic/research \\
Strategic partnership \\
institutions, entrepreneurial start-ups and other potential \\
partners. \\
influence, engage) \\
Build and manage relationships with ecosystem partners \\
(e.g., universities, startups, other R\&D labs) designed to \\
discover new business opportunities \\
Engage with the innovation ecosystem and to identify and \\
develop high impact opportunities. \\
Within our OI ecosystem, manage key external partner \\
engagements \\
Manage the network of open innovation partners. \\
Collaborative development of open innovation strategy in the \\
context of innovation management. \\
Create \& develop Open Innovation strategy that focuses on \\
technology, talent and partners while incorporating an \\
experimental discovery mindset. \\
Development of new strategies to get ideas, resources and \\
technology from the outside.
\end{tabular}




\begin{tabular}{|c|c|}
\hline Key areas of responsibility & Examples of Roles and Responsibilities \\
\hline \multirow[t]{4}{*}{ Project Management } & The execution of open innovation projects. \\
\hline & $\begin{array}{l}\text { Manage technology projects with strategic partners, } \\
\text { universities and/or Corporate R\&D Tech Leads to develop } \\
\text { prototypes / products with business stakeholders and } \\
\text { external manufacturing partners }\end{array}$ \\
\hline & $\begin{array}{l}\text { Manage technology development projects for technologies } \\
\text { that may be adjacent or transformative to the traditional } \\
\text { businesses. }\end{array}$ \\
\hline & $\begin{array}{l}\text { To manage multiple projects concurrently moving them } \\
\text { through planning to delivery and execution. }\end{array}$ \\
\hline \multirow[t]{5}{*}{$\begin{array}{l}\text { Cross-functional } \\
\text { management }\end{array}$} & $\begin{array}{l}\text { Partners in cross functional teams to develop and manage } \\
\text { technology strategies }\end{array}$ \\
\hline & $\begin{array}{l}\text { Works closely with packaging, process development, and } \\
\text { manufacturing to identify technology needs, working to } \\
\text { then identify potential external solutions }\end{array}$ \\
\hline & $\begin{array}{l}\text { Work cross-functionally to communicate competitive insights } \\
\text { within the beverage/snack category and to the broader } \\
\text { organization. }\end{array}$ \\
\hline & $\begin{array}{l}\text { Interact cross functionally with customers, account teams, } \\
\text { partners, architects, peers }\end{array}$ \\
\hline & $\begin{array}{l}\text { Organize, plan, and manage cross-functional, high visibility } \\
\text { initiatives within the Open Innovation team }\end{array}$ \\
\hline \multirow{6}{*}{$\begin{array}{l}\text { Open Innovation } \\
\text { platforms/internal and } \\
\text { external crowdsourcing } \\
\text { (to manage, design) }\end{array}$} & Crowdsourcing communities \\
\hline & $\begin{array}{l}\text { Care of crowdsourcing community on the platform and } \\
\text { support of the local community }\end{array}$ \\
\hline & Manage open innovation platforms \\
\hline & Design open innovation activities (e.g. prizes, challenges) \\
\hline & $\begin{array}{l}\text { Open Innovation platforms - craft challenges, } \\
\text { crowdsourcing }\end{array}$ \\
\hline & $\begin{array}{l}\text { Organize and manage external and internal crowdsourcing } \\
\text { initiatives to collect new ideas from employees }\end{array}$ \\
\hline \multirow{3}{*}{$\begin{array}{l}\text { Open Innovation events } \\
\text { (to manage, design, } \\
\text { organize, coordinate) }\end{array}$} & Manage and coordinate Open Innovation events. \\
\hline & $\begin{array}{l}\text { Design and conduct events with partners (e.g. workshops, } \\
\text { students' events). }\end{array}$ \\
\hline & $\begin{array}{l}\text { Deliver experiences and workshops with start-ups and } \\
\text { ecosystem partners. }\end{array}$ \\
\hline \multirow[t]{2}{*}{$\begin{array}{l}\text { IP Management } \\
\text { (emphasized the least) }\end{array}$} & $\begin{array}{l}\text { Develop ownership strategies (IO) and implementation plans } \\
\text { for technology platforms }\end{array}$ \\
\hline & $\begin{array}{l}\text { Structure strategic deals (equity investment, commercial } \\
\text { and/or } M \& A \text { ) }\end{array}$ \\
\hline
\end{tabular}

While analyzing the job offers with open innovation in the title, we used Nvivo10 to map the pattern of the most frequently used words (see Fig. 5. Word tree for pattern in words: network, partners, ecosystem in 23 job descriptions with open innovation in the title.). Apart from job responsibilities in building and managing the network of partners, 
the word networking was also used as a desired qualification (e.g. the person should have a strong technology/start-up/academic network or should demonstrate experience in network management). Other common words were partners and ecosystem, this also supports our main findings that companies place the responsibilities of engaging and building ecosystems, as well as building relationships with various partners, in the hands of open innovation specialists.

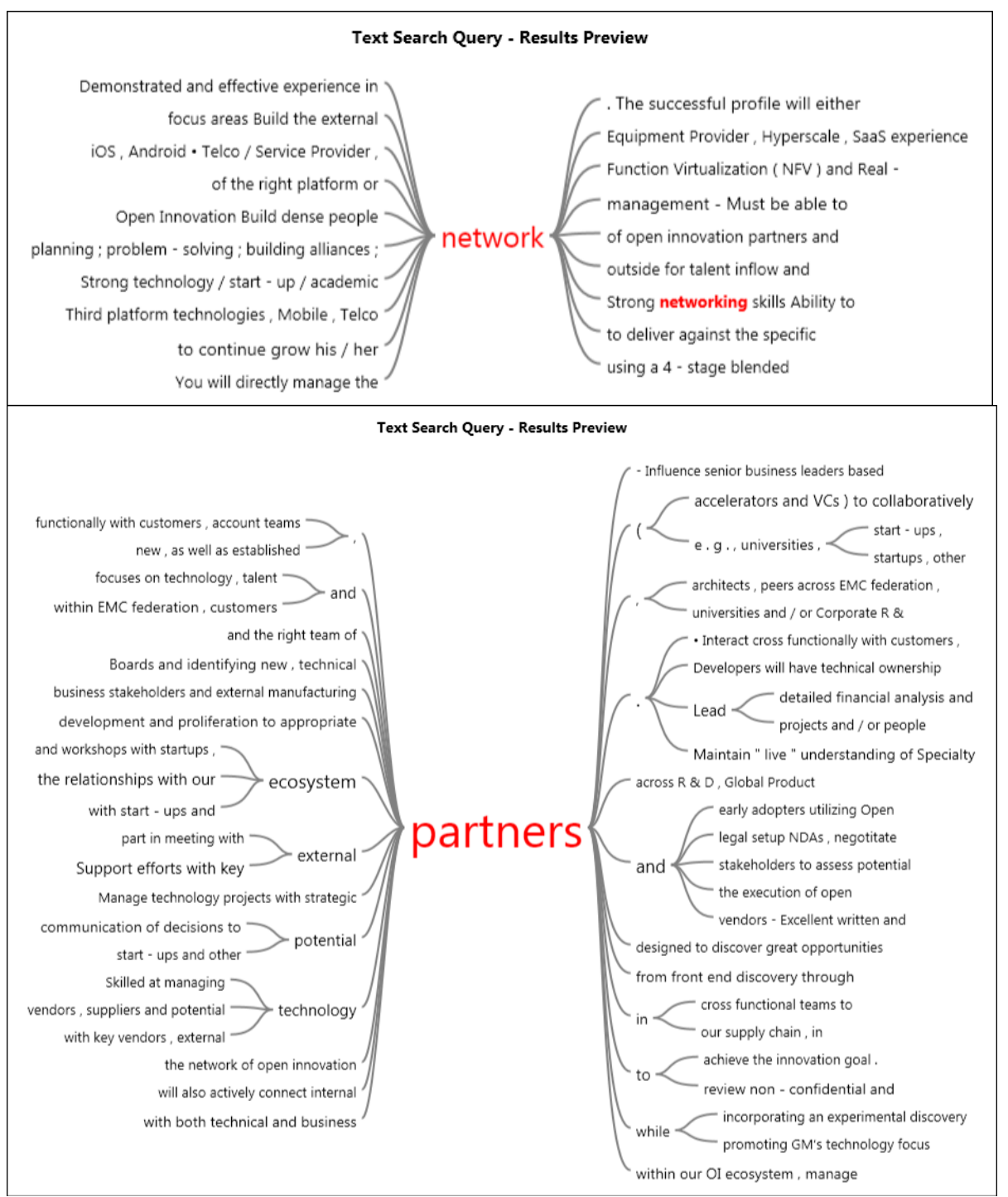




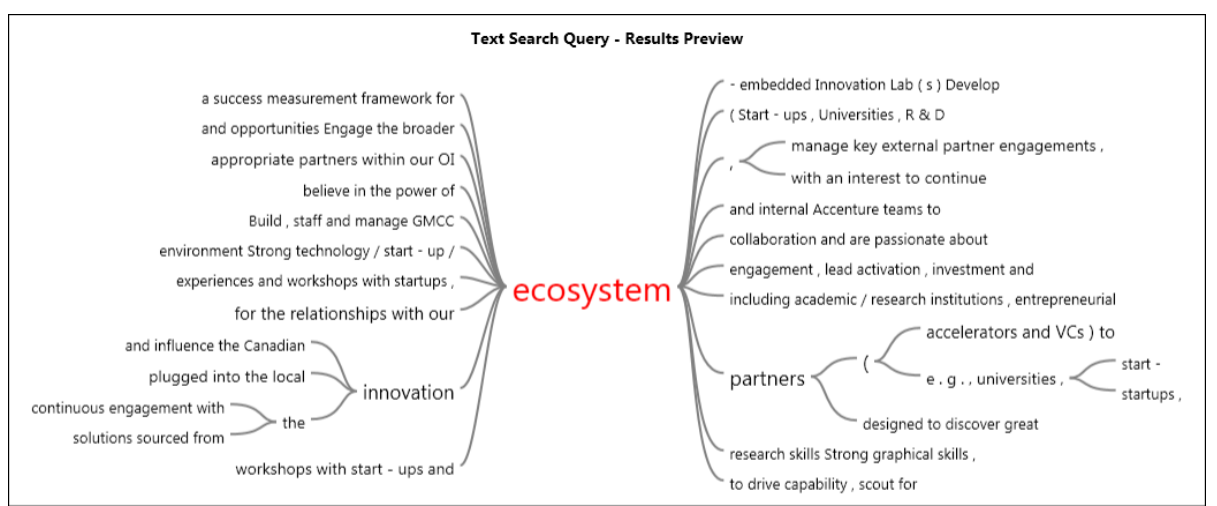

Fig. 5. Word tree for pattern in words: network, partners, ecosystem in 23 job descriptions with open innovation in the title.

\subsection{The evolution of jobs related to open innovation}

This section focuses on presenting findings based on the comparison of job advertisements with 'open innovation' in the title and in the job description posted in 2014 with the ones posted in 2016. As mentioned in the first section, the jobs advertisements with a clear open innovation function have boomed.

Interestingly, it can be noted that in 2016, compared to 2014, companies placed stronger attention on the ability to influence others as a job requirement, with a proven track record and experience in this domain. In addition, in case of positions of open innovation professionals, influencing was part of the job responsibility (See Table 3 for details).

Table 3. List of job titles mentioning the 'ability to influence others' in jobs posted in 2016.

\begin{tabular}{|c|c|c|c|}
\hline Job Title & Industry & Roles and Responsibilities & Job requirements \\
\hline $\begin{array}{l}\text { Open Innovation } \\
\text { Consultant; } \\
\text { Open Innovation } \\
\text { Business } \\
\text { Strategy Analyst }\end{array}$ & Consulting & $\begin{array}{l}\text { he/she will lead and deliver } \\
\text { results through influence } \\
\text { and building alliances. }\end{array}$ & $\begin{array}{l}\text { Ability to deliver results } \\
\text { through alliances and } \\
\text { influence }\end{array}$ \\
\hline $\begin{array}{l}\text { Open Innovation } \\
\text { Manager }\end{array}$ & Electronics & $\begin{array}{l}\text { Influence senior business } \\
\text { leaders based upon business } \\
\text { strategies to identify and } \\
\text { acquire external technology } \\
\text { to deliver on current and } \\
\text { future business deliverables }\end{array}$ & \\
\hline $\begin{array}{l}\text { Senior Software } \\
\text { Engineer, Open } \\
\text { Innovation Lab }\end{array}$ & $\begin{array}{l}\text { Engineering, } \\
\text { Software }\end{array}$ & & $\begin{array}{l}\text { Ability and track record of } \\
\text { influencing and } \\
\text { collaborating with others }\end{array}$ \\
\hline $\begin{array}{l}\text { Head of Open } \\
\text { Innovation }\end{array}$ & Automotive & $\begin{array}{l}\text { develop and influence the } \\
\text { innovation ecosystem to } \\
\text { drive capability, scout for } \\
\text { emerging technology, foster } \\
\text { external partnerships and }\end{array}$ & $\begin{array}{l}\text { Highly capable networker } \\
\text { that holds established } \\
\text { credibility with external } \\
\text { stakeholders as a thought } \\
\text { leader and influencer }\end{array}$ \\
\hline
\end{tabular}




\begin{tabular}{|c|c|c|c|}
\hline Job Title & Industry & Roles and Responsibilities & Job requirements \\
\hline & & $\begin{array}{l}\text { incubate strategic } \\
\text { collaborations }\end{array}$ & \\
\hline Project Leader & Pharmaceutical & $\begin{array}{l}\text { Apply your technical, } \\
\text { commercial and influencing } \\
\text { skills to strengthen the } \\
\text { adoption of Bio-based } \\
\text { materials across our global } \\
\text { organization }\end{array}$ & $\begin{array}{l}\text { Outstanding } \\
\text { communications and } \\
\text { influencing skills including } \\
\text { fluent written and spoken } \\
\text { English }\end{array}$ \\
\hline $\begin{array}{l}\text { Connected } \\
\text { Home Architect }\end{array}$ & Power and Gas & & $\begin{array}{l}\text { Someone who can lead } \\
\text { multi-functional teams and } \\
\text { stakeholders typically } \\
\text { through influence in a } \\
\text { complex matrix organization } \\
\text { Strong people leader with } \\
\text { exceptional stakeholder } \\
\text { management skills and the } \\
\text { ability to operate and } \\
\text { influence at all levels. }\end{array}$ \\
\hline $\begin{array}{l}\text { Market Analyst } \\
\text { Leader/Senior } \\
\text { Manager }\end{array}$ & $\begin{array}{l}\text { Home } \\
\text { Appliance }\end{array}$ & & $\begin{array}{l}\text { Excellent organizational, } \\
\text { communication, and } \\
\text { influencing skills }\end{array}$ \\
\hline $\begin{array}{l}\text { Director- } \\
\text { Treatment and } \\
\text { Analytics }\end{array}$ & Manufacturing & & $\begin{array}{l}\text { Strong influence } \\
\text { management capability } \\
\text { needed }\end{array}$ \\
\hline $\begin{array}{l}\text { Engineering } \\
\text { Supervisor }\end{array}$ & Aerospace & & $\begin{array}{l}\text { Must be able to influence } \\
\text { peers on the relationship } \\
\text { between scope, schedule, } \\
\text { and resources. }\end{array}$ \\
\hline $\begin{array}{l}\text { I\&R } \\
\text { Refrigeration } \\
\text { Innovation } \\
\text { Intern }\end{array}$ & $\begin{array}{l}\text { Building } \\
\text { Technologies }\end{array}$ & & $\begin{array}{l}\text { Ability to work effectively } \\
\text { and influence others in a } \\
\text { diverse and dynamic work } \\
\text { environment }\end{array}$ \\
\hline $\begin{array}{l}\text { Senior Manager } \\
\text { Emerging } \\
\text { Technologies }\end{array}$ & Chemicals & & $\begin{array}{l}\text { Understanding and } \\
\text { influencing OEM strategies } \\
\text { concerning applications and } \\
\text { material solutions }\end{array}$ \\
\hline $\begin{array}{l}\text { Technology } \\
\text { Scout }\end{array}$ & $\begin{array}{l}\text { Information } \\
\text { Services }\end{array}$ & & $\begin{array}{l}\text { Effectively communicating } \\
\text { and presenting technical } \\
\text { complex data (both verbally } \\
\text { and written) to influence all } \\
\text { levels and global audiences } \\
\text { High degree of emotional } \\
\text { intelligence and excellent } \\
\text { facilitation and influencing } \\
\text { skills. } \\
\text { Effective leadership, } \\
\text { communication and } \\
\text { influencing skills are } \\
\text { necessary for success in this } \\
\text { role }\end{array}$ \\
\hline
\end{tabular}




\begin{tabular}{|c|c|c|c|}
\hline Job Title & Industry & Roles and Responsibilities & Job requirements \\
\hline & & & $\begin{array}{l}\text { Ability to influence decision- } \\
\text { making is critical to bringing } \\
\text { complex issues to successful } \\
\text { conclusion. }\end{array}$ \\
\hline $\begin{array}{l}\text { Associate } \\
\text { Principal } \\
\text { Engineer Team } \\
\text { Leader }\end{array}$ & $\begin{array}{l}\text { Consumer } \\
\text { Goods }\end{array}$ & & $\begin{array}{l}\text { Strong organizational } \\
\text { positioning skills with a } \\
\text { demonstrated ability to } \\
\text { influence through } \\
\text { organizational awareness } \\
\text { and effective, clear } \\
\text { communication }\end{array}$ \\
\hline $\begin{array}{l}\text { Digital } \\
\text { Innovation } \\
\text { Management }\end{array}$ & $\begin{array}{l}\text { Consumer } \\
\text { Goods }\end{array}$ & & $\begin{array}{l}\text { Ability to influence peers } \\
\text { and management (IT, non- } \\
\text { IT, internal and external) to } \\
\text { drive project and process } \\
\text { outcomes }\end{array}$ \\
\hline
\end{tabular}

Research indicates that there was another new requirement in 2016 - the candidate's prior start-up experience, which was not emphasized in 2014 (see Table 4). Also, surprisingly knowledge of IP management was not indicated as often as a job requirement compared to 2014, where it was highlighted more than twice as often as in 2016.

On the other hand, the entrepreneurial skills/mindset were mentioned more often in 2014 compared to 2016 and were related to positions of technology scout (chemicals), leader open innovation (consumer goods), consumer market \& intelligence (healthcare, cosmetics), and program manager (power and gas).

Table 4. List of job titles in 2016 emphasizing start-up experience and entrepreneurial skills.

\begin{tabular}{|c|c|c|c|}
\hline Job Title & Industry & Roles and Responsibilities & Job requirements \\
\hline $\begin{array}{l}\text { Head of Open } \\
\text { Innovation }\end{array}$ & Automotive & & Startup experience \\
\hline $\begin{array}{l}\text { Open Innovation } \\
\text { Senior Manager }\end{array}$ & $\begin{array}{l}\text { ITC } \\
\text { Manufacturing } \\
\text {, Computer } \\
\text { Hardware, } \\
\text { Electronics }\end{array}$ & $\begin{array}{l}\text { Identify strategic innovation } \\
\text { targets (startups and/or early } \\
\text { stage technologies) } \\
\text { Evaluation and competitive } \\
\text { analysis of startup } \\
\text { technologies }\end{array}$ & \\
\hline $\begin{array}{l}\text { Open Innovation } \\
\text { Consultant; Open } \\
\text { Innovation } \\
\text { Business Strategy } \\
\text { Analyst }\end{array}$ & Consulting & $\begin{array}{l}\text { Relationships with our } \\
\text { ecosystem partners (e.g., } \\
\text { universities, startups, other } \\
\text { R\&D labs) designed to } \\
\text { discover new business } \\
\text { opportunities }\end{array}$ & $\begin{array}{l}\text { Prior experience in } \\
\text { startups } \\
2+\text { years of technical } \\
\text { start-up or } \\
\text { entrepreneurial } \\
\text { experience with } \\
\text { enterprise technologies }\end{array}$ \\
\hline $\begin{array}{l}\text { New Business } \\
\text { Opportunity } \\
\text { Manager }\end{array}$ & Healthcare & $\begin{array}{l}\text { Responsible for establishing } \\
\text { mutually beneficial } \\
\text { relationships with startups } \\
\text { and entrepreneurs. }\end{array}$ & $\begin{array}{l}\text { knowledge: } \\
\text { accelerators, start-ups, } \\
\text { incubators is a } \\
\text { differentiation }\end{array}$ \\
\hline
\end{tabular}




\begin{tabular}{|c|c|c|c|}
\hline Job Title & Industry & Roles and Responsibilities & Job requirements \\
\hline PhD student & ICT Software & $\begin{array}{l}\text { Support intra- and } \\
\text { entrepreneurship challenges } \\
\text { (hackathons) with employees, } \\
\text { students and startups. }\end{array}$ & \\
\hline $\begin{array}{l}\text { Intern Digital } \\
\text { Ventures }\end{array}$ & Consulting & & $\begin{array}{l}\text { Have working } \\
\text { experience in e.g. } \\
\text { consulting, startups or } \\
\text { tech-/ engineering- } \\
\text { driven environments }\end{array}$ \\
\hline $\begin{array}{l}\text { Director } \\
\text { Innovation } \\
\text { Incubator }\end{array}$ & $\begin{array}{l}\text { Financial } \\
\text { services }\end{array}$ & & Start-up experience \\
\hline $\begin{array}{l}\text { Senior Director } \\
\text { Transactions }\end{array}$ & $\begin{array}{l}\text { Pharmaceutica } \\
1\end{array}$ & & $\begin{array}{l}\text { Knowledge: IP } \\
\text { management; start-ups; } \\
\text { strategic management } \\
\end{array}$ \\
\hline $\begin{array}{l}\text { Digital } \\
\text { Innovation } \\
\text { Management }\end{array}$ & $\begin{array}{l}\text { Consumer } \\
\text { Goods }\end{array}$ & & $\begin{array}{l}\text { Ability to influence } \\
\text { peers and management } \\
\text { (IT, non-IT, internal and } \\
\text { external) to drive } \\
\text { project and process } \\
\text { outcome }\end{array}$ \\
\hline
\end{tabular}

\section{Discussion}

In this rapidly changing and networked business environment, our findings indicate that firms are increasingly creating specific open innovation functions and designing completely new roles. This responds to previous calls for empirical inquiries addressing the "human side" of open innovation research (e.g. Mortara and Minshall, 2014; Podmetina et al., 2013; Vanhaverbeke at al., 2014; West at al., 2006).

Due to our curiosity about who the specialists are behind open innovation adoption, we have explored the roles and responsibilities of open innovation specialists and addressed the skills and competencies related to these roles. It is clear that research in this area is scarce. Thus, we analyzed 100 job advertisements related to open innovation profiles. We identified the most desired set of skills for open innovation professionals (i.e. excellent communication skills, leadership and project management skills, problem-solving, strategic thinking and ability to work in cross-functional teams, interpersonal skills, ability to work independently and as part of the team, and ability to influence others). Concerning knowledge, most of the job offers mentioned crossdisciplinary knowledge. Interestingly, the entrepreneurial skills/mindset were not considered as important, which contrasts with the findings of other researchers (e.g. Cloyd and Euchner, 2012; Dodgson et al., 2006; Di Minin et al., 2010, Mortara et al., 2009). However, the data indicate that companies pay attention to a proven track record and emphasize prior experience with start-ups as a main job requirement. This may suggest that large companies try to increase the collaboration with start-ups, and seek experienced candidates who are not influenced by corporate mentality.

When comparing the two periods when we collected our data, significant changes were 
observed. First of all, the number of job profiles indicating 'open innovation' in the title of the job increased. The analysis revealed that in 2016, compared to 2014, companies shifted toward creating, sustaining and influencing the ecosystem. Not surprisingly, the ability to influence others was becoming more emphasized as part of the job requirements. The job requirements were focused more on prior experience and proven track record (especially for managerial positions), rather than on candidates' skills and knowledge. To build and manage relationships with ecosystem partners (e.g. universities, start-ups, other R\&D labs); scouting for emerging technologies looking for business opportunities both inside the firm and outside - these are just a few examples of roles and responsibilities assigned to open innovation candidates. Furthermore, cross-functional cooperation was considered an important part of the OI specialist's daily routine. Cross-functional cooperation is considered as internal openness in some studies (e.g. Love et al., 2011), stressing that it also aims at increasing the innovation output of the firm (Powell et al., 1996; Tsai, 2001; van den Bosch et al., 1999). Interestingly, some companies extended the responsibilities to tasks related to human resource management (e.g. talent management, recruitment, selection and training), indicating the true multidisciplinarity that is expected from the right candidates.

In addition, our findings indicate that even though open innovation was originally coined as a paradigm shift within large manufacturing firms, it has rapidly extended to new industries, supporting the findings of other academics (Chesbrough and Bogers, 2014). Furthermore, our findings suggest that the open innovation function has spread beyond traditional R\&D and innovation departments toward strategic management, marketing and sales, corporate communications, and even IT and purchasing departments.

The relatively small number of public job advertisements related explicitly to 'Open Innovation' specialists, when compared to the LinkedIn profiles of over 52,000 positions, can be explained by the conclusions of Vanhaverbeke et al. (2017) who found that open innovation managers usually have long tenures in the company. This indicates internal promotions without the need to go public and search for new specialists. This fact also addresses the question whether companies prefer to train employees on open innovation rather than hire external open innovation professionals (Podmetina et al., 2013).

\section{Conclusions and avenues for further research}

This paper provides a significant contribution to the open innovation field of research by triggering the discussion on essential skills of employees in firms implementing (or planning to implement) open innovation. It presents an interdisciplinary approach by integrating open innovation and human resource management research streams, and by analyzing job profiles of open innovation professionals. It calls for new research on HRM and open innovation by developing sets of skills and competencies needed for the successful adoption of open innovation, providing training and education recommendations for industry, consulting and higher education, and bringing the role of the individual to the front of open innovation research. In addition, the results contribute to the current stream of innovation literature by identifying the key areas of 
roles and responsibilities of open innovation professionals. To the best of our knowledge, prior to this study there was no attempt to analyze job advertisements related to open innovation that aimed to identify the skills, roles and responsibilities of open innovation specialists in companies.

The results of this study can be used by companies for creating job descriptions and/or planning to recruit new staff. Moreover, they can be used by universities or other educational institutions while developing the curricula. For example, considering the fact that the majority of the job advertisements stressed that candidates should possess cross-disciplinary knowledge (be it the combination of technology and business, R\&D with marketing and management, or R\&D and sales management), it can be argued that open innovation should be taught not only on innovation management majors/programs/courses, but should also be available for students from other departments such as engineering, chemistry, biology, pharmaceutical etc. At the same time, basic knowledge of marketing, management and sales should be emphasized, with focus on developing and improving communication, leadership and problem-solving skills. We anticipate that the results will create a discussion on required and desired skills of employees in companies adopting or planning to adopt open innovation, as well as job responsibilities of open innovation professionals.

This study also has some limitations. First, it is based on the analysis of job advertisements that were posted in specific periods in 2014 and 2016, and only reflects jobs advertised in English. This means that it does not include companies with open innovation professionals that were not seeking to recruit new staff at the time. Second, due to the sample size and adopted research methodology, the results cannot be statistically generalized. Third, as indicated by Carliner and colleagues (2015) we acknowledge that job descriptions and advertisements may not match the actual job responsibilities, as they may reflect over-idealized expectations of the position, or in line with findings by Mathews and Redman (2001) they may be poorly designed by unexperienced recruiting organizations.

In order to improve the validity and generalizability of the results, future research could analyze the importance of personal traits and individual skill endowment (c.f. Bianchi and colleagues, 2011). In addition, interviews with companies with open innovation divisions could shed light on the actual roles and responsibilities of open innovation professionals. As the findings reveal the growing importance of open innovation professionals in building and influencing the ecosystems, as well as emphasize candidates' prior experience in working with start-ups, we call for further research in this domain. Furthermore, this study opens new horizons for teaching open innovation, both within university curricula and for practical business training. It sheds light on the importance of practical skills and experience and the necessity of on-the-job training, and puts pressure on transforming teaching methods to more interactive and practiceoriented ones.

\section{$7 \quad$ Acknowledgements}

The earlier version of this paper was presented at the XXVII ISPIM Innovation Conference - Blending Tomorrow's Innovation Vintage, Porto, Portugal on 19-22 June 
2016.

The data leading to this article were collected by the European Academic Network for Open Innovation (OI-Net project), which received funding from the European Union Lifelong Learning Programme under the Grant Agreement Number 2013-3830 (http://oi-net.eu).

\section{$8 \quad$ References}

Ahn, J.M., Minshall, T., \& Mortara, L., (2017). Understanding the human side of openness: the fit between open innovation modes and CEO characteristics. $R \& D$ Management, 47(5), 727-740

Alexy, O., Henkel, J., \& Wallin, M.W., (2013). From closed to open: Job role changes, individual predispositions, and the adoption of commercial open source software development. Research Policy, 42(8),1325-1340.

Aguinis, H., Michaelis, S.E. \& Jones, N.M., (2005). Demand for certified human resources professionals in internet-based job announcements. International Journal of Selection and Assessment, 132), 160-171.

Asakawa, K., Nakamura, H. \& Sawada, N. (2010), Firms' open innovation policies, laboratories' external collaborations, and laboratories' R\&D performance, $R \& D$ Management, 4O(2),109-123.

Baker, J.A. \& Cissell, W. B.,(1994). Professionalism and academic job announcements in health education. Wellness Perspectives 10(4), 40-47.

Bayona-Saez, C., Cruz-Cázares, C., García-Marco, T. \& Sánchez García, M., (2017). Open innovation in the food and beverage industry. Management Decision, 55 (3), pp

Bianchi, M., Chiaroni, D., Chiesa, V. \& Frattini, F. (2011), Exploring the role of human resources in technology out-licensing: an empirical analysis of biotech new technology-based firms, Technology Analysis \& Strategic Management, 23(8), 825-849.

Boettger, R.K. \& Palmer, L.A. (2010), Quantitative content analysis: Its use in technical communication, Professional Communication, IEEE Transactions on. 53(4), 346357.

Bogers, M., Foss, N.J. \& Lyngsie, J. (2018), The "human side" of open innovation: The role of employee diversity in firm-level openness. Research Policy, 47(1), 218231.

Boon, J. \& van der Klink, M. (2002), Competencies: The triumph of a fuzzy concept, Academy of Human Resource Development Annual Conference, Honolulu, HA, 27 February-3 March, Proceedings, 1, 327-334.

Caputo, M., Lamberti, E., Cammarano, A. \& Michelino, F., (2016). Exploring the impact of open innovation on firm performances. Management Decision, 54(7), 1788-1812.

Carliner, S., Castonguay, C., Sheepy, E., Ribeiro, O., Sabri, H., Saylor, C. \& Valle, A., (2015). The job of a performance consultant: a qualitative content analysis of job 
descriptions. European Journal of Training and Development, 39(6), 458-483.

Chatenier, E. D., Verstegen, J. A., Biemans, H. J., Mulder, M., \& Omta, O. S. (2010), Identification of competencies for professionals in open innovation teams, $R \& D$ Management, 40(3), 271-280.

Chen, T., Chang, P., \& Yeh, C. (2004), A Study of Career Needs, Career Development Programs, Job Satisfaction and the Turnover Intentions of R\&D Personnel, Career Development International. 9(4),424-437.

Chen, H.L. \& Zhang, Y., (2017). Educating Data Management Professionals: A Content Analysis of Job Descriptions. The Journal of Academic Librarianship, $43(1), 18-24$.

Cheng, C.C. \& Shiu, E.C., (2015). The inconvenient truth of the relationship between open innovation activities and innovation performance. Management Decision, 53(3), 625-647.

Chesbrough, H. (2003), Open Innovation: The New Imperative for Creating and Profiting from Technology. Cambridge, MA: Harvard Business Review Press.

Chesbrough, H., Vanhaverbeke, W. \& West, J. (2006), Open innovation: Researching a new paradigm, Oxford: Oxford University Press.

Chesbrough, H. \& Crowther, A. K. (2006), Beyond high tech: early adopters of open innovation in other industries, $R \& D$ Management, 36(3), 229-236.

Chesbrough, H, (2011). Bringing open innovation to services. MIT Sloan Management Review, 52(2), 85.

Chesbrough H (2012) Open Innovation: Where We've Been and Where We're Going, Research-Technology Management, 55(4), 20-27

Chesbrough, H. \& Bogers, M. (2014), Explicating open innovation: clarifying an emerging paradigm for understanding innovation, New Frontiers in Open Innovation. Oxford: Oxford University Press, 3-28.

Chesbrough, H. W. \& Brunswicker, S. (2014), A fad or a phenomenon?: The adoption of open innovation practices in large firms, Research-Technology Management, $57(2), 16-25$

Chatenier, E.D., Verstegen, J.A., Biemans, H.J., Mulder, M. \& Omta, O.S. (2010), Identification of competencies for professionals in open innovation teams, $R \& D$ Management, 4O(3), 271-280.

Christensen, J.F., Olesen, M.H. \& Kjær, J.S., 2005. The industrial dynamics of Open Innovation-Evidence from the transformation of consumer electronics. Research policy, 34(10), 1533-1549.

Cloyd, G. \& Euchner, J. (2012), Building open innovation at P\&G: An interview with Gil Cloyd, Research Technology Management 55, 14-19.

Cseh, M. (2003), Facilitating learning in multicultural teams, Advances in Developing Human Resources, 5(1), 26-40.

CSTD (2010), Competencies for Training and Development Professionals, Canadian Society for Training and Development, Toronto.

Colombo, M.G. \& Grilli, L. (2005), Founders' human capital and the growth of new 
technology-based firms: A competence-based view, Research policy, 34(6), 795816.

Currie, G., \& Kerrin, M. (2003), Human resource management and knowledge management: enhancing knowledge sharing in a pharmaceutical company, The International Journal of Human Resource Management, 14(6), 1027- 1045.

Dahlander, L. \& Gann, D.M. (2010), How open is innovation?, Research Policy, 39(6), 699-709.

Dąbrowska, J., Fiegenbaum, I. \& Kutvonen, A., 2013. Mapping the perception and reality of open innovation. International Journal of Innovation Management, 17(06), 1340016.

Dabrowska, J. \& Podmetina, D. (2014), Identification of Competences for Open Innovation. In ISPIM Conference Proceedings (p. 1), The International Society for Professional Innovation Management (ISPIM).

Di Minin, A., Frattini, F., \& Piccaluga, A. (2010), Fiat: open innovation in a downturn (1993- 2003), California Management Review, 52, 132.

Dodgson, M., Gann, D. \& Salter A. (2006), The role of technology in the shift towards open innovation: The case of Procter \& Gamble, R\&D Management, 36,.333346.

Enkel, E., Gassmann O. \& Chesbrough H. (2009), Open R\&D and open innovation: Exploring the phenomenon, $R \& D$ Management, 39(4), 311-316.

Fleming, L. \& Waguespack, D.M. (2007), Brokerage, boundary spanning, and leadership in open innovation communities. Organization Science, 18(2), 165180.

Gassmann, O., Enkel, E. \& Chesbrough, H. (2010), The future of open innovation, R\&D Management, 40(3), 213-221.

Gassmann, O. \& Enkel, E. (2004), Towards a theory of open innovation: Three core process archetypes, Presented at the R\&D Management Conference (RADMA). Lisabon, Portugal.

Hacievliyagil, N. K. \& Auger, J.-F. (2010). What does open innovation implies for the management of R\&D? Two cases of multinational firms. Bureau d'économie théorique et appliquée, Université de Strasbourg.

Hafkesbrink, J. \& Schroll, M. (2010), Organizational Competences for open innovation in small and medium sized enterprises of the digital economy, Competence Management for Open Innovation: Tools and It Support to Unlock the Innovation Potential Beyond Company Boundaries, 30,.21.

Huston, L. \& Sakkab N. (2006), Connect and develop: Inside Procter \& Gamble's new model for innovation, Harvard Business Review, 84, 8-66.

Kanter R.M. (2006), Innovation: The classic traps, Harvard Business Review, 84,7283.

Kanungo, M. H. Y., \& Misra, S. (1992), Managerial resourcefulness: a reconceptualization of management skills, Human Relations, 56, 1311-32.

Katz, R. \& Allen, T.J., (1982), Investigating the Not Invented Here (NIH) syndrome: A look at the performance, tenure, and communication patterns of $50 \mathrm{R} \& \mathrm{D}$ Project 
Groups. $R \& D$ Management, 12(1), 7-20.

Krippendorff, K., (2012). Content analysis: An introduction to its methodology. Sage

Laursen, K. \& Salter, A. (2006), Open for Innovation: The role of openness in explaining innovation performance among UK manufacturing firms, Strategic Management Journal, 27, 131-150.

Lindegaard, S. \& G. Kawasaki. (2010), The Open Innovation Revolution: Essentials, Roadblocks and Leadership Skills, London: Wiley.

Lichtenthaler, U. (2007), The drivers of technology licensing: An industry comparison, California management review, 49(4), 67-89.

Lichtenthaler, U. (2008), Open innovation in practice: an analysis of strategic approaches to technology transactions, Engineering Management, IEEE Transactions, 55(1), 148-157.

Lichtenthaler, U. \& Ernst, H. (2008), Innovation intermediaries: why internet marketplaces for technology have not yet met the expectations, Creativity and innovation management, 17(1), 14-25.

Lichtenthaler, U. (2010), Technology exploitation in the context of open innovation: Finding the right 'job' for your technology, Technovation, 3a(7), 429-435.

Martino, G. \& Bartolone, J. (2011). Soft skills for open innovation success. In ed. P. Sloane, A Guide to Open Innovation and Crowdsourcing: Advice from Leading Experts (pp. 98-105). London, Philadelphia, New Delhi: Kogan Page.

Mathews, B. P. \& Redman, T. (2001). Recruiting the wrong salespeople: are the job ads to blame?. Industrial Marketing Management, 30(7), 541-550.

Mortara, L., Napp, J., Slacik, J., Minshall, T. (2009), How to implement open innovation: Lessons from studying large multinational companies, University of Cambridge Institute for Manufacturing.

Mortara, L. \& Marshall T. (2011), How do large multinational companies implement open innovation?, Technovation, 31, 586-597.

Mortara, L. \& Minshall, T. (2014), Patterns of Implementation of OI in MNCs Oxford: Oxford University Press, 242-255.

Mulder, M. (2007), Competence: the essence and use of the concept in ICVT, European Journal of Vocational Training, 40, 5-22.

Nakata, C. \& Im, S. (2010), Spurring Cross-Functional Integration for Higher New Product Performance: A Group Effectiveness Perspective, Journal of Product Innovation Management, 27 (4), 554-571.

Naqshbandi, M.M. \& Naqshbandi, M.M.,(2016). Managerial ties and open innovation: examining the role of absorptive capacity. Management Decision, 54(9), 22562276.

Noh, Y., (2015). Financial effects of open innovation in the manufacturing industry. Management Decision, 53(7), 1527-1544.

Park, J.R. \& Lu, C., (2009), Metadata professionals: Roles and competencies as reflected in job announcements, 2003-2006. Cataloging \& Classification Quarterly, 47(2), 145-160. 
Petroni, G., Venturini, K. \& Verbano, C. (2012), Open innovation and new issues in $\mathrm{R} \& \mathrm{D}$ organization and personnel management, The International Journal of Human Resource Management, 23(1), 147-173.

Podmetina, D., Volchek, D., Dąbrowska, J. \& Fiegenbaum, I. (2013). Human Resource Practices and Open Innovation. International Journal of Innovation Management, 17(06).

Podmetina, D., Fiegenbaum, I., Teplov, R. \& Albats, E. (2014), Towards open innovation measurement system-a literature review In ISPIM Conference Proceedings (p. 1), The International Society for Professional Innovation Management (ISPIM).

Powell, W.W., Koput, K.W. \& Smith-Doerr, L. (1996), Interorganizational collaboration and the locus of innovation: Networks of learning in biotechnology, Administrative science quarterly,.116-145.

Prahalad, C.K. \& Hamel, G. (1990), The core competence of the corporation, Harvard Business Review, 68,.9-91.

Proctor, R.W. \& Dutta, A. (1995), Skill Acquisition and Human Performance, London: Sage.

Ritter, T. \& Gemünden., H. G. (2003), Inter-organizational relationships and networks: An overview, Journal of Business Research, 56, 691-697.

Rychen, D. S. E. \& Salganik, L. H. E. (2003), Key competencies for a successful life and $a$ well-functioning society, Hogrefe \& Huber Publishers.

Saebi, T. \& Foss, N. J. (2015). Business models for open innovation: Matching heterogeneous open innovation strategies with business model dimensions. European Management Journal, 33(3), 201-213.

Salter, A., Criscuolo, P. \& Ter Wal, A.L., (2014). Coping with Open Innovation. California Management Review, 56(2), 77-94.

Sandberg, J. (2000), Understanding human competence at work: an interpretative approach, Academy of management journal, 43(1), 9-25.

Sartori, R., Favretto, G. \& Ceschi, A. (2013), The relationships between innovation and human and psychological capital in organizations: A review, The Innovation Journal: The Public Sector Innovation Journal, 18(3), article 2.

Schroll, A. \& Mild, A. (2011), Open innovation modes and the role of internal R\&D: An empirical study on open innovation adoption in Europe, European Journal of Innovation Management, 14(4), 475-495.

Sloane, P. (2011), A Guide to Open Innovation and Crowdsourcing: Advice from Leading Experts. London: Kogan Page.

Shahbazi, R. \& Hedayati, A., (2016). Identifying Digital Librarian Competencies According to the Analysis of Newly Emerging IT-based LIS Jobs in 2013. The Journal of Academic Librarianship, 42(5), 542-550.

Shank, J.D., (2006). The blended librarian: A job announcement analysis of the newly emerging position of instructional design librarian. College \& Research Libraries, 67(6), 514-524.

Shockley-Zalabak, P.S. (2008), Fundamentals of organizational communication, 
Boston: Allyn \& Bacon.

Söderlund, J., \& Bredin, K. (2006), HRM in project-intensive firms: Changes and challenges, Human resource management, 45(2), 249-265.

Tang, Y.,(2013). Distance education librarians in the United States: A study of job announcements. The Journal of Academic Librarianship, 39(6), 500-505.

Thong, R. \& Lotta, T. (2015), Creating a Culture of Productivity and Collaborative Innovation: Orion's R\&D Transformation, Research-Technology Management, $58(3), 41-51$.

Trott, P. \& Hartmann, D.A.P. (2009), Why'open innovation'is old wine in new bottles, International Journal of Innovation Management, 13(4), 715-736.

Tsai, W. (2001), Knowledge transfer in intraorganizational networks: Effects of network position and absorptive capacity on business unit innovation and performance, Academy of management journal, 44(5),996-1004.

Van Den Bosch, F.A., Volberda, H.W. \& De Boer, M. (1999), Coevolution of firm absorptive capacity and knowledge environment: Organizational forms and combinative capabilities, Organization science, 10(5), 551-568.

Van der Meer, H. (2007), Open innovation-the Dutch treat: challenges in thinking in business models, Creativity and innovation management, 16(2), 192-202.

Van de Vrande, V., De Jong, J.P., Vanhaverbeke, W. \& De Rochemont, M. (2009), Open innovation in SMEs: Trends, motives and management challenges, Technovation, 29(6), 423-437.

Vanhaverbeke, W., West, J. \& Chesbrough, H. (2014), Surfing the new wave of open innovation research. In: Chesbrough, H., Vanhaverbeke, W. and West, J. (Eds), New Frontiers in Open Innovation, New York: Oxford University Press.

Vanhaverbeke, W. \& Chesbrough, H. (2014), A classification of open innovation and open business models, H. Chesbrough, W. Vanhaverbeke \& J. West (Eds.), New Frontiers in Open Innovation,.50-68.

Vanhaverbeke,W., Cheng, \& Chesbrough, H. (2017), A Profile of Open Innovation Managers in Multinational Companies, Accessed 24 November 2017. Website: http://www.innovationmanagement.se/2017/03/09/open-innovation-managers-inmultinational-companies/

West, J., Vanhaverbeke, W. \& Chesbrough, H. (2006), Open innovation: a research agenda. In: Chesbrough, H., Vanhaverbeke, W. and West, J. (Eds), Open Innovation: Researching a New Paradigm, New York: Oxford University Press.

WEF, (2016), The Future of Jobs Employment, Skills and Workforce Strategy for the Fourth Industrial Revolution, The Future of Jobs Report. Switzerland: World Economic Forum.

West, J. \& Bogers, M. (2013), Leveraging External Sources of Innovation: A Review of Research on Open Innovation, Journal of Product Innovation Management, 31(4), 814-831.

Wynarczyk, P., Piperopoulos, P., \& McAdam, M. (2013), Open innovation in small and medium-sized enterprises: An overview, International Small Business Journal, 0266242612472214. 
Zhang, Y.W.\& Wildemuth, B.M. (2010), Qualitative analysis of content, Applications of Social Research Methods to Questions in Information and Library, 1-12.

Zobel, A.K., (2017). Benefiting from Open Innovation: A Multidimensional Model of Absorptive Capacity. Journal of Product Innovation Management. 34(3), 269288. 